\title{
Pre-service Teachers' Use of Turkish on the Internet
}

\author{
Muamber Yılmaz \\ Department of Basic Education, Faculty of Education, Bartin University, Turkey
}

Copyright $(2017$ by authors, all rights reserved. Authors agree that this article remains permanently open access under the terms of the Creative Commons Attribution License 4.0 International License

\begin{abstract}
Aim of this study was to determine situation of pre-service primary school teachers' use of Turkish on the internet. The research was conducted on 100 students studying at the department of Primary School Education of Mustafa Kemal University. The research was descriptive. Data of the study was obtained from the students' conversations in Facebook in the preceding month. Percentages were applied for the analysis of statistical operations. As a result of the study, the students' mistakes made while using Turkish on the internet were categorized into three groups which were phonetic features, vocabulary use and spelling. Consequently, it was revealed that $62 \%$ of pre-service primary school teachers used undotted letters instead of Turkish letters, $83 \%$ of them did not use vowels, $58 \%$ of them made phone repetitions in stress-aimed words, and $50 \%$ of them wrote time affixes improperly.
\end{abstract}

Keywords Pre-service Primary School Teachers, Internet, Use of Turkish, Turkish

\section{Introduction}

Our age is era of communication. Communication has become more functional than ever before. Especially mass media's becoming popular has highly affected communication. When globalization is regarded as well, it can be said that there has been great improvement in speed and function of communication. With technological improvements, communication channels have been changing and new channels have been added. Communication used today has left its place to communication used on the internet.

With recent global developments, people's way of communication and perception of the world has substantially changed, and computers and internet have come into prominence [32]. Internet is a large computer net spread all over the world [18]. Internet has spread at a great pace since it has provided convenient access to information and has made information spread quickly [9]. Today, the internet; has become an important source of information for families, students and teachers. Internet has made a communication revolution since it can reach each point of our work and living spaces [23]. Social networking sites are highly important in communication carried through internet. Social media is a communication tool which is mostly preferred by young people and which is very interesting for them. The Internet is a point, which access to information from the adolescents, facilitates research, so that, while the agenda as a resource to support the development of skills such as critical thinking, problem solving, creativity [3]; from another point extreme, depending on the purpose of use out of control and is also believed to adversely affect the development of personal skills ([5]; [19]). People can share their ideas, discuss on these ideas and create new ideas on social media. Additionally, they can share various photographs and videos, look for jobs and experience real world on virtual platform. This makes people tend towards this platform day by day [36].

The following conclusions were reported in a study conducted about social media:

- Two out of every three people in the world use social network.

- 100 million videos are watched on YouTube every day, and videos for 20 hours are uploaded per minute.

- $\quad$ People spend 8 billion minutes on Facebook, and 285 million contents are shared every day.

- While $65.1 \%$ of internet users use e-mail, $68 \%$ of them use social network.

- Turkey, with more than 14 million users, is the third most active country using Facebook.

- Turkey is the country spending the most time on the internet in Europe [13].

Today increase in the problematic internet use was observed with increasing use of the internet [29]. The rigging of Internet usage time has revealed the problem of internet addiction [28]. The majority of research on Internet addiction has been conducted with college students and adults ([2]; [11]; [21]). While social networking sites provide some advantages to the users such as communication, fast communication, helping socializing and quick access to information, they have some drawbacks, too. The biggest drawback is that language is damaged and it degenerates. 
New communication symbols, usage patterns and communication codes used on the internet deeply affect structure of languages [8]. Yaman and Erdoğan [37] states that applications based on not using some sounds in the words for decreasing time in speaking words and making pronunciation easier, which means least effort law in spoken language are also faced in written language on the internet. All languages are under the effect of new linguistic formations appeared with internet [31]. Some linguists, has expressed that the bells rang for other languages with the progress in becoming a universal language English [6]. Furthermore Turkish, like other languages, is exposed to pressure of English. It is true that young people use Turkish improperly by violating Turkish grammar rules, and this situation is rapidly becoming widespread. This situation causes Turkish to degenerate in virtual world. This careless usage affects phonetic, vocabulary and sentence structure of Turkish in a negative way, which may cause non-recoverable results in the future.

It has to be spoken in accordance with the Turkish grammar structure in every setting (formal or informal settings). It must speak with Istanbul Turkish in formal setting. Besides in formal or informal the conversation must be adhered to Turkish grammar structure. Otherwise this situation causes Turkish to degenerate in future.

When studies conducted on this subject were analyzed, this situation clearly drew our attention. Kabaday1 [14], Aksüt et al. [1], Çakır and Topçu [8], O'brien et al. [24] and Merchant [22] investigated effects of internet on language. On the other hand, Tarcan [30] revealed that English is dominant in virtual world, and other languages are passive against English.

Tosun [34] reported that Turkish has received a lot of words from English and other European languages recently, and those words have caused Turkish grammar rules to be damaged and our language to degenerate. Özezen [25] expressed in his study conducted on the students of Turkish Language and Literature, Statistics and Computer Engineering that there were a lot of mistakes made about language on the internet after analyzing spelling of Turkish on the internet. Temur and Vuruş [33] discussed that phonetic features of Turkish were ignored on the internet and Turkish was used improperly on internet environment. On the other hand, Kara [15] found in his study that with social network's becoming widespread among a lot of people, linguistic mistakes increased, internet increased problems like not being able to use language accurately and using slang words. Aksüt, Batur and Avşar [1] concluded that with technological improvements, grammar rules were violated in virtual world, and new characters that had not been used in Turkish started to be used. Gülsevin [12] stated that this degeneration stemmed from people's admiration for the western world. Their admiration was generally performed by using English words and this caused degeneration in the language.

Using language for communication is a necessity. Whole communication, either written or verbal expression, is based on language. It is necessary to use the language suitable for its rules in order to express the message accurately. It is because of the fact that a language is cultural heritage of a nation. Saving it and transferring it to the next generations are duties of every citizen.

Our language is getting dirty by foreign words' usage and is losing its own cultural value. While there are various reasons of this situation, the most important reason is written and verbal press; that is mass media [20]. Yildirım and Tahiroğlu [38] claimed that internet causes rapid improvement and change in a language; however, it also has some positive characteristics such as spreading language, teaching Turkish more easily and effectively, conveying more information to people in a shorter time via e-libraries. Today, language has come to a position to lose its purity since language usage is not cared on media and internet which were revealed by communication culture [33].

Importance given to Turkish by pre-service teachers who will guide the posterity is really important with regard to the students they will educate and to the future of Turkish. When it is considered that these pre-service teachers are class teachers that teach literacy and make the students gain basic skills, the importance increases. That is why, it is necessary that pre-service class teachers who will be the first ones making students gain basic skills should use language in the most accurate way in order to teach Turkish to the students accurately and completely. Pre-service teachers knowing grammar structure of Turkish, speaking and writing in compliance with this grammar structure will not only educate next generation as individuals speaking and writing beautifully but they will also contribute to our language to be transferred to the future. In this study, the way of class teachers' using Turkish on the internet and the mistakes they made were revealed.

\subsection{Aims}

Aim of the research was to investigate how class teachers used Turkish on the internet and what kind of mistakes they made while using Turkish. The following questions were tried to be answered:

1. How can pre-service class teachers' mistakes that they made about morphological characteristics of Turkish while using it be categorized?

2. While pre-service class teachers were using Turkish on the internet;

a How can mistakes they made about phonetic features be categorized?

b To what extent they made mistakes about phonetic features?

3. While pre-service class teachers were using Turkish on the internet;

c How can mistakes they made about vocabulary usage be categorized? 
d To what extent they made mistakes about vocabulary usage?

4. While pre-service class teachers were using Turkish on the internet;

e How can spell mistakes they made be categorized?

f To what extent they made spelling mistakes?

\section{Materials and Methods}

This research was descriptive-oriented, and survey model was employed in the study. Survey model aims to describe an existing situation as it is [17].

\subsection{Population and Sample}

Population of the research consisted of Facebook conversations of students studying at the department of Primary School Education of Mustafa Kemal University Faculty of Education. The sample included Facebook conversations of 100 students selected from the department of Primary School Education.

\subsection{Data Collection Instruments}

Data analysis Facebook conversations (informal settings) of Primary School Education students were used as data collection tools. Content analysis of Facebook conversations of 100 students studying at the department of Primary School Education of Mustafa Kemal University Faculty of Education was conducted. As a result of this analysis, the students' mistakes about using Turkish on the internet were separated into three groups. These were mistakes made about phonetic features of Turkish, use of vocabulary and spelling rules.

Mistakes made about phonetic features while using Turkish on the internet were classified like this: using undotted letters (c, 1, s, g, o, u) instead of Turkish characters (ç, i, ö, ş, ü, ğ) (For instance: Disarı, gorusuruz etc.). Using "v" instead of "w" and "k" instead of "q" (For example: Ewe, çoq etc.). Not using " $r$ " at the end of the words (bi sürü, bi şey etc.).

Mistakes made about vocabulary use were classified as: Not using vowels in a word (For instance: Slm, nbr etc.). Not using consonants in a word (For example: Geliorum etc.). Using letter of "z" instead of "s" (For instance: Güsel, k1s etc.). Phone repetitions stress-aimed words (For example: Çoook etc.). Using Turkish and English words together (For example: Pc, free etc.).

Mistakes made about spelling rules were classified as: Writing "-de, -da" conjuctions adjunctively. Writing "-ki" conjunction adjunctively. Writing "-mi" interrogative affix adjunctively (değilmi? etc.). Using emotional words (haha, hih etc.). Writing time affixes improperly (For example: Çıkmıcaz, bilemicem etc.).

Firstly, letters were given to these mistakes under three main categories, then these letters were expressed as numbers, and frequencies were determined.

\subsection{Data Analysis}

Percentage were used in data analysis.

\section{Results}

Data obtained through the research are illustrated in tables.

Table 1. Example Mistakes Made Related to Phonetic Features While Using Turkish on The Internet by Pre-Service Teachers at The Department of Primary School Education

\begin{tabular}{|c|c|}
\hline Correct Use & Wrong Use \\
\hline çok & çoq \\
\hline devam & dewam \\
\hline evet & ewet \\
\hline var & war \\
\hline sınav & sinaw \\
\hline beğenmiyorum & begnmyn \\
\hline söylesin & boylesn \\
\hline biraz & bıraz \\
\hline çıkmadı & cıkmadı \\
\hline dişarı & dısarı \\
\hline görüşürüz & gorusuruz \\
\hline çalış & calıs \\
\hline birkaç & bikaç \\
\hline bir şey & bişey \\
\hline
\end{tabular}

Table 2. Percentage Table of Mistakes Made Related to Phonetic Features While Using Turkish on The Internet by Pre-Service Teachers at The Department of Primary School Education

\begin{tabular}{|c|c|c|c|}
\hline $\begin{array}{c}\text { Mistakes Made Related to } \\
\text { Phonetic Features }\end{array}$ & $\begin{array}{c}\text { Students } \\
\text { Making } \\
\text { Mistakes }\end{array}$ & $\begin{array}{c}\text { Students not } \\
\text { Making } \\
\text { Mistakes }\end{array}$ & \multirow{2}{*}{ Total } \\
\cline { 2 - 3 } & $\%$ & $\%$ & \\
\hline $\begin{array}{c}\text { Using undotted letters (c,1,s,g,o,u) } \\
\text { instead of Turkish characters } \\
\text { (ç,i,o,s,s,u, }, \mathrm{g})\end{array}$ & 62 & 38 & \multirow{2}{*}{100} \\
\hline $\begin{array}{c}\text { Using "W" instead of "V" and "Q" } \\
\text { instead of "K" }\end{array}$ & 28 & 72 & \\
\hline $\begin{array}{c}\text { Not using "r" at the end of the } \\
\text { words }\end{array}$ & 20 & 80 & \\
\hline
\end{tabular}

When Table 2 is analyzed, $62 \%$ of pre-service teachers used undotted letters instead of Turkish characters while using Turkish on the internet. For instance, they used disarı instead of dişarı or gorusuruz instead of görüşürüz. Furthermore, it was found that $28 \%$ of pre-service teachers used letters which are not in Turkish alphabet like "w" and "q" (ewet instead of evet, çoq instead of çok), and 20\% of them did not use " $r$ " at the end of the words (bi şey instead of bir şey, etc.). 
Table 3. Example Mistakes Made Related to Vocabulary Use While Using Turkish on The Internet by Pre-Service Teachers at The Department of Primary School Education

\begin{tabular}{|c|c|}
\hline Correct Use & Wrong Use \\
\hline merhaba & $\mathrm{mrb}$ \\
\hline iyi & ii \\
\hline değil & de1l \\
\hline bencillik & bencllk \\
\hline selam & $\operatorname{slm}$ \\
\hline tamam & $\mathrm{tmm}$ \\
\hline ortak & ortk \\
\hline görüşürüz & görşrz \\
\hline bugün & bugn \\
\hline bilmiyorum & bilmiorum \\
\hline k1z & k1s \\
\hline güzel & güsel \\
\hline bilgisayar & $\mathrm{P}^{\mathrm{c}}$ \\
\hline boş & free \\
\hline tamam & ok \\
\hline sağol & saol \\
\hline evet & evetttttt \\
\hline çok & çoooook \\
\hline yalan & yalannn \\
\hline tamam & tamammm \\
\hline
\end{tabular}

Table 4. Percentage Table of Mistakes Made Related to Vocabulary Use While Using Turkish on The Internet by Pre-Service Teachers at The Department of Primary School Education

\begin{tabular}{|c|c|c|c|}
\hline \multirow{2}{*}{$\begin{array}{c}\text { Mistakes Made Related to } \\
\text { Vocabulary Use }\end{array}$} & $\begin{array}{c}\text { Students } \\
\text { Making } \\
\text { Mistakes }\end{array}$ & $\begin{array}{c}\text { Students not } \\
\text { Making } \\
\text { Mistakes }\end{array}$ & \multirow{2}{*}{ Total } \\
\cline { 2 - 3 } & $\%$ & $\%$ & \\
\hline Not using vowels in the words & 83 & 17 & \multirow{2}{*}{100} \\
\hline $\begin{array}{c}\text { Not using consonants in the } \\
\text { words }\end{array}$ & 35 & 65 & \\
\hline Using "S" instead of "Z" & 10 & 90 & \\
\hline $\begin{array}{c}\text { Phone repetitions in } \\
\text { stress-aimed words }\end{array}$ & 58 & 42 & \\
\hline $\begin{array}{c}\text { Using Turkish and English } \\
\text { words together }\end{array}$ & 4 & 96 & \\
\hline
\end{tabular}

When Table 4 is studied, a great part of the students in the department of primary school education (83\%) did not write vowels in the words while communicating on the internet (like writing mrb instead of merhaba). It was revealed that the rate of students' not using consonants in the words while using Turkish was 35\% (like using geliorum instead of geliyorum). It was found that $10 \%$ of pre-service teachers made the mistake of using "s" instead of " $\mathrm{z}$ " (like using k1s instead of $\mathrm{k1z}$ ), $58 \%$ of them made some phone repetitions in some words (çoooook etc.), and 4\% of them made the mistake of using Turkish and English words together (like writing free tak1liyorum).
Table 5. Example Mistakes Made Related to Spelling Rules While Using Turkish on The Internet by Pre-Service Teachers at The Department of Primary School Education

\begin{tabular}{|c|c|}
\hline Correct Use & Wrong Use \\
\hline gelecek misin & gelecekmisin \\
\hline gelemeyeceğim & gelemicem \\
\hline demek ki & demekki \\
\hline değil mi? & değilmi? \\
\hline ona da söyle & onada söyle \\
\hline yeter ki & yeterki \\
\hline çıkıorum & çıkıom \\
\hline
\end{tabular}

Table 6. Percentage Table of Mistakes Made Related to Spelling Rules While Using Turkish on The Internet by Pre-Service Teachers at The Department of Primary School Education

\begin{tabular}{|c|c|c|c|}
\hline $\begin{array}{c}\text { Mistakes Made Related to } \\
\text { Spelling Rules }\end{array}$ & $\begin{array}{c}\text { Students } \\
\text { Making } \\
\text { Mistakes }\end{array}$ & $\begin{array}{c}\text { Students not } \\
\text { Making } \\
\text { Mistakes }\end{array}$ & \multirow{2}{*}{ Total } \\
\cline { 2 - 3 } & $\%$ & $\%$ & \\
\hline $\begin{array}{c}\text { Writing "-de, -da" conjunctions } \\
\text { adjunctively }\end{array}$ & 17 & 83 & \multirow{2}{*}{100} \\
\hline $\begin{array}{c}\text { Writing "-ki" conjunction } \\
\text { adjunctively }\end{array}$ & 4 & 96 & \\
\hline $\begin{array}{c}\text { Writing "-mi" interrogative affix } \\
\text { adjunctively }\end{array}$ & 27 & 73 & \\
\hline Using emotional words & 3 & 97 & \\
\hline Writing time affixes improperly & 50 & 50 & \\
\cline { 1 - 3 }
\end{tabular}

As shown in Table 6, students of primary school education mostly made the mistake of writing time affixes improperly while using Turkish on the internet (like using gelmicem instead of gelmeyeceğim). This type of mistake was followed by writing "-mi" interrogative affix adjunctively with $27 \%$, writing "-de, -da" conjunctions adjunctively with $17 \%$, writing "-ki" conjunction adjunctively with $4 \%$ and using emotional words with $3 \%$ (haha, hih etc.).

\section{Conclusion and Discussion}

It was concluded that pre-service class teachers did not obey grammar rules while using Turkish on the internet. The mistakes they made were classified into 3 categories as phonetic features, vocabulary use and spelling. Mistakes made about phonetic features were using undotted letters instead of Turkish letters, using w instead of $\mathrm{v}$, q instead of $\mathrm{k}$, and not using $\mathrm{r}$ at the end of the words. Mistakes made about vocabulary use were not writing vowels in the words, not writing consonants in the words, phone repetitions in stress-aimed words, using "s" instead of " $z$ ", and using Turkish and English words together. On the other hand, mistakes made about spelling were writing -de, -da conjunctions adjunctively, writing -ki conjunction adjunctively, writing $-\mathrm{mi}$ interrogative affix adjunctively, using emotional words and writing time affixes improperly. Additionally, it was revealed that $62 \%$ of pre-service primary school teachers used undotted letters instead of Turkish 
letters, $83 \%$ of them did not use vowels, $58 \%$ of them made phone repetitions in stress-aimed words, and $50 \%$ of them wrote time affixes improperly.

When findings of this study were compared with other researches, similar findings were observed. Temur and Vuruş [33] reported that Turkish was used carelessly on the internet, phonetic features of Turkish were not taken into consideration, spelling rules were neglected and word and sentence structures were not complied. Karahisar [16] revealed that while using Turkish on the internet, young generations performed some behaviors such as omitting vowels from the words, abbreviating words in spoken language and showing their feelings by using symbols that consist of punctuations. When those findings were compared with the findings of this study, similar results were observed. This was because of the fact that in this study, pre-service teachers omitted vowels from the words while using Turkish on the internet, too. For instance; (Slm, Mrb, Tmm, etc.).

Yaman and Erdoğan [37] suggested that written language was used carelessly and improperly on the internet, and a lot of mistakes were made about language. In the current study, it was also found that Turkish was used carelessly on the internet without obeying grammar rules, and a lot of grammar mistakes were made. $83 \%$ of the pre-service teachers did not use vowels. Since these mistakes were made by pre-service teachers, the matter gained more importance. Moreover, Bulut [4], Ertuğrul and Keskin [10], Çağlak [7], Ulaş and Sevim [35], Kara [15], Tarcan [30], Özezen [25], Aksüt, Batur and Avşar [1] pointed out that Turkish was used improperly on the internet. This result is similar to the result of this study. Additionally, Sis [27] revealed that language used in media is degenerated day by day, and this degeneration results from lack of mother tongue awareness and having admiration for words of other languages. If the state of using Turkish improperly on the internet goes on, this degeneration will continue, too. This may lead bigger problems in the future.

\section{REFERENCES}

[1] Aksüt, M., Batur, Z. \& Avşar,T. (2006). Sanalca, sanal odalarda (internet) iletişim ve Türkçe. Akademik Bilişim Konferansı, Pamukkale Üniversitesi, Denizli.

[2] Bakken, I. J., Wenzel, H. G., Göstestam, K. G., Johansson, A. \& Oren, A. (2009). Internet addiction among Norwegian adults: A stratified probability sample study. Scandinavian Journal of Psychology, 50 (2), 121-127.

[3] Berson I. \& Berson M. (2003). Digital literacy for effective citizenship. Social Education, 67(3),164-167.

[4] Bulut, S. (2014). İmla ve telaffuz sorununda telefon ile internetin rolü. Tarih Okulu Dergisi, 17, 831-849.

[5] Colwell, J. \& Kato, M. (2003). Investigation of the relationship between social isolation, self-esteem, aggression and computer game play in Japanese adolescents. Asian Journal of Social Psychology, 6(2), 149-158.

[6] Crystal, D. (2002). Language and the internet. Cambridge: Cambridge University Press.

[7] Çağlak, E. (2003). Kitle iletişim araçlarında Türkçenin yanlış kullanımı. İstanbul Ticaret Üniversitesi Dergisi, 4, 129-136.

[8] Çakır, H. \& Topçu, H. (2005). Bir iletişim dili olarak İnternet. Erciyes Üniversitesi Sosyal Bilimler Enstitüsü Dergisi, 19(2), 71-96.

[9] Ergin, A. (2005). Öğretim teknolojisi ve iletişim. Ankara: Anı Yayınc1lik.

[10] Ertuğrul, İ \& Keskin, N. (2012). İnternetin Türkçenin kullanımında ve toplu-birey yapısının değişimindeki rolü. Internet Uygulamaları ve Yönetimi, 3(2), 79-88.

[11] Ferraro, G., Caci, B. D’Amico, A. \& Blasi, M. (2007). Internet addiction aisorder: An Italian study. Cyberpsychology \& Behevior, 10(2), 170-175.

[12] Gülsevin, G. (2006). "Dil kirliliği sorunu". (Ed: Gürer Gülsevin ve Erdoğan Boz), Türkçenin Çağdaş Sorunlarl, Ankara: Gazi Yayınevi, p.135-164.

[13] http://www.muratkahraman.net/

[14] Kabaday1, O. (2006). Ağ ortamındaki Türkçeye genel bir bakış. Türk Dili Dil ve Edebiyat Dergisi, Cilt XCI (652), 298-314.

[15] Kara, M. (2006). İnternet Türkçesinin çı̆̆lığı: Türkçe dili ve diğerleri. Akademik Araştırmalar Dergisi, 30, 157-170.

[16] Karahisar, T. (2013). Dijital nesil, dijital iletişim ve dijitalleşen Türkçe. Online Academic Journal of Information Technology, 12(4), 71-82.

[17] Karasar, N. (2009). Bilimsel araştırma yöntemi. Ankara: Nobel Yayınlar1.

[18] Kennedy, A. J. (2000). The internet, the rough guide. (Çev: Ş. Demir). Ankara: Dost Kitabevi.

[19] Kerber, C.J. (2005). Problem and pathological gambling among college athletes. Ann Clin Psychiatry, 17(4), 243-247.

[20] Kıbrıs, İ. (2011). Türkçe sözlü anlatim güzel konuşma/diksiyon. Ankara: Kök Yayıncılık.

[21] Leung, L. (2004). Net-generation attributes and seductive properties of the internet addiction. Cyberpsychology \& Behavior, 7(3), 333-348.

[22] Merchant, G. (2001). Teenagers in cyberspace: an investigation of language use and language change in internet chatrooms. Journal of Research in Reading, 24(3), 293-306.

[23] Neumann, M. O’Murchu, I., Breslin, J., Decker, S., Hogan, D. and MacDonaill, C. (2005). Semantic social network portal for collaborative online communities. Journal of European Industrial Training, 29(6),472-487

[24] O'brien, D. G., Moje, E. B. \& Stewart, R. A. (2001). Construction of Literacy. New Jersey: Lawrence Erlbaum Associates.

[25] Özezen, M. (2010). Türkçenin ağ ortamındaki yazımı ve bunun ses bilimsel yapıyla bağlantıları. Bilig Dergisi, 53, $233-256$ 
[26] Pfoeffer, P. (2002). Web usability and children: Current research and implication for information professinals. Orana, $38(2), 11-13$

[27] Sis, N. (2006). "Medya dili sorunu". (Ed. Gürer Gülsevin \& Erdoğan Boz), Türkçenin Çăgdaş Sorunları, Ankara: Gazi Yayınevi, p.247-284.

[28] Shapira, N. A., Lessig, M. C., Goldsmith, T.d., Szabo, S. T., Lazortz, M., Gold, M. S. \& Stein, D. J. (2003). Problematic internet use: Propose classification and diagnostic criteria. Depress Anxiety, 17(4), 207-216.

[29] Spada, M. M. (2014). An Overview of Problematic Internet Use, Addictive behaviors, 39 (1), 3-6.

[30] Tarcan, A. (2006). Sanal dünyada dil savaşları. Üniversite ve Toplum Dergisi, 6 (1), 1-9.

[31] Tattersal, A. (2003). The internet and French language. Center for Language in Education Occasional Papers, University of Southampton, ED: 4477228.

[32] Tayfun, R. (2010). Etkili iletişim ve beden dili. Ankara: Nobel Yayıncilik.
[33] Temur, T. \& Vurus, N. (2009). İnternet (genel ağ) ortamında Türkçenin kullanımına ilişkin bir çözümleme. Balıkesir Üniversitesi Sosyal Bilimler Enstitüsü Dergisi, 12(22), 232244.

[34] Tosun, C. (2005). Dil zenginliği, yozlaşma ve Türkçe. Journal of Language and Linguistic Studies, 1 (2), 136-154.

[35] Ulaş, A. H. \& Sevim, O. (2010). İnternet ortamındaki Türkçenin genel durumu. Ekev Akademi Dergisi, 44, 185-192.

[36] Vural, Z. B. A. \& Bat, M. (2010). Yeni bir iletişim ortamı olarak sosyal medya: Ege Üniversitesi iletişim fakültesine yönelik bir araştırma. Journal of Yasar University. 20(5), 3348-3382.

[37] Yaman, H. \& Erdoğan, Y. (2007). İnternet kullanımının Türkçeye etkileri: Nitel bir araştırma. Journal of Language and Linguistic Studies, 3(2), 237-249.

[38] Yıldırım, F. \& Tahiroğlu, T. (2006). "İnternette Türkçe kullanımı sorunu". (Ed: Gürer Gülsevin Erdoğan Boz), Türkçenin Çağdaş Sorunları, Ankara: Gazi Yayınevi, p.361-378. 